Shin-Huei Chiou
Ming-Feng Huang
Huan-Tsung Chang

Department of Chemistry, National Taiwan University, Taipei, Taiwan, R.O.C.

\section{Separation of double-stranded DNA fragments by capillary electrophoresis: Impacts of poly(ethylene oxide), gold nanoparticles, ethidium bromide, and $\mathrm{pH}$}

\begin{abstract}
The separation of DNA by capillary electrophoresis using poly(ethylene oxide) (PEO) containing gold nanoparticles (GNPs) is presented. The impacts of PEO, GNPs, ethidium bromide $(\mathrm{EtBr})$, and $\mathrm{pH}$ on the separation of double-stranded DNA have been carefully explored. Using a capillary dynamically coated with $5.0 \%$ poly(vinylpyrrolidone) and filled with $0.2 \%$ PEO containing $0.3 \times$ GNPs (the viscosity less than $15 \mathrm{cP}$ ), we have demonstrated the separation of DNA markers $\mathrm{V}$ and $\mathrm{VI}$ within $5 \mathrm{~min}$ at $\mathrm{pH} 8.0$ and 9.0. In terms of resolution and reproducibility, GNPs have a greater impact on the separation of DNA at pH 9.0. Resolution improvements for large DNA fragments ( $>300$ base pairs, bp) are greater than those for small ones in the presence of GNPs. It is important to point out that reproducibility is excellent (relative standard deviations for the migration times less than $0.5 \%$ ) and thus no further dynamic coating is required in at least 20 consecutive runs in the presence of GNPs. Using $0.2 \%$ PEO (pH 9.0) containing $0.3 \times$ GNPs, the separation of DNA fragments ranging in size from 21 to $23130 \mathrm{bp}$ was accomplished in $7 \mathrm{~min}$. The results presented in this study show the advantage of PEO containing GNPs for DNA separation, including rapidity, high resolving power, excellent reproducibility, and ease of filling capillaries.
\end{abstract}

Keywords: Capillary electrophoresis / DNA / Gold nanoparticles / Poly(ethylene oxide)

DOI 10.1002/elps.200405977

\section{Introduction}

Capillary electrophoresis (CE) in conjunction with laserinduced fluorescence (LIF) is a powerful tool for DNA sequencing and the analyses of PCR products [1-3]. Its success is due in part to the use of entangled and uncrosslinking polymer solutions that provide advantages over cross-linking gel, including easy preparation, low viscosity, and flexibility [4]. Of considerably importance and widely used polymer solutions are those prepared from polyacrylamide [1], poly(ethylene oxide) (PEO) [5, 6], hydroxyethylcellulose (HEC) [7, 8], poly(vinylpyrrolidone) (PVP) [9], poly- $N, N$-dimethylacrylamide (PDMA) [10]. Owing to the self-coating ability of these polymers, any tedious coating processes are prevented and problems associated with coating inhomogeneity, capillary fouling,

Correspondence: Dr. Huan-Tsung Chang, Department of Chemistry, National Taiwan University, Section 4, Roosevelt Road, Taipei, Taiwan, R.O.C.

E-mail: changht@ntu.edu.tw

Fax: +011-886-2-23621963

Abbreviations: EtBr, ethidium bromide; GNPs, gold nanoparticles; PEO, poly(ethylene oxide); TEM, transmission electron microscopy; SPR, surface plasma resonance and limited shelf life are minimized. However, a high-pressure means is generally needed to fill capillaries with highly viscous polymer solutions that provide high sieving ability and long DNA read length.

To overcome the difficulty of filling capillaries, low-viscosity sieving matrices containing additives such as urea [11], mannitol [12], and montmorillonite clay [13] have been used for DNA separation. Very recently, we have tested the DNA separation using PEO containing gold nanoparticles (GNPs). The separation of DNA ranging in size from 8 to 2176 base pairs (bp) was accomplished in 5 min using $0.2 \%$ PEO $\left(M_{\mathrm{r}} 8000000\right)$ containing $56 \mathrm{~nm}$ GNPs [14]. The low-viscosity PEO solution $(<15 \mathrm{cP})$ offers a faster DNA separation while providing comparable resolution to that using 2.0\% PEO solution (high viscosity). We have also demonstrated the separations of the DNA fragments ranging from 5 to $40 \mathrm{kbp}$ using $0.05 \%$ PEO $\left(M_{\mathrm{r}} 2000000\right)$ containing $13 \mathrm{~nm}$ GNPs and $0.05 \%$ PEO $\left(M_{\mathrm{r}} 4000000\right)$ containing $32 \mathrm{~nm}$ GNPs, respectively. The improvement in the reproducibility and resolution for DNA has also been presented using a $75 \mu \mathrm{m}$ separation channel on a poly(methyl methacrylate) (PMMA) plate that was dynamically coated in sequence with PVP, PEO, and $13 \mathrm{~nm}$ GNPs [15]. 
Our previous studies $[14,15]$ have indicated that the relative sizes of GNPs to PEO and buffer compositions are important parameters in determining DNA separation. In this study, we further investigate the effect of $\mathrm{pH}$, concentrations of GNPs, PEO, and ethidium bromide (EtBr) on DNA separations. The separation of DNA ranging in size from $21 \mathrm{bp}$ to $23.1 \mathrm{kbp}$ was accomplished in $7 \mathrm{~min}$ by using $0.2 \%$ PEO $(\mathrm{pH}$ 9.0) containing $0.3 \times$ GNPs and $0.5 \mu \mathrm{g} / \mathrm{mL} \mathrm{EtBr}$, with excellent reproducibility (relative standard deviation (RSD) for the migration times for all DNA fragments are $<0.5 \%$ ).

\section{Materials and methods}

\subsection{Chemicals}

Sodium tetrachloroaurate(III) dihydrate, PEO ( $\left.M_{\mathrm{r}} 8000000\right)$, and PVP were obtained from Aldrich (Milwaukee, WI, USA). Trisodium citrate and sodium hydroxide were purchased from Riedel-de Haën (Seelze, Germany). Glycine was obtained from ICN Biomedicals (Aurora, OH, USA). DNA molecular weight markers $\mathrm{V}$ (pBR 322/Haelll digest) and VI (pBR 328/Bgll and Hinfl digest) were purchased from Roche Diagnostics (Mannheim, Germany). EtBr, $\phi X$ 174 RF DNA-Haelll digest, and lambda DNA Hindlll digest were purchased from Pharmacia Biotech (Uppsala, Sweden). Please note that $\mathrm{EtBr}$ is a highly carcinogenic compound and must be handled with wearing gloves. The $\mathrm{pH}$ values of glycine buffers were adjusted to $7.0-10.0$ with $\mathrm{NaOH}$.

\subsection{Apparatus}

The basic design of the separation system has been previously described [16]. Briefly, a high-voltage power supply (Gamma High Voltage Research, Ormond Beach, FL, USA) was used to drive electrophoresis. The entire detection system was enclosed in a black box with a highvoltage interlock. The high-voltage end of the separation system was housed in a plexiglass box for safety. A 4.0 mW He-Ne laser with $543.5 \mathrm{~nm}$ output from Uniphase (Mantense, CA, USA) was used for excitation. The emission light was collected with a $20 \times$ objective (numeric aperture $=0.40$ ). One RG 610 cutoff filter was used to block scattered light before the emitted light reached the phototube (R928; Hamamatsu Photonics K. K., ShizuokaKen, Japan). The fluorescence signal was transferred directly through a $10 \mathrm{k} \Omega$ resistor to a 24 bit $A / D$ interface at $10 \mathrm{~Hz}$ (Borwin; JMBS Developments, Le Fontanil, France) and stored in a PC. Capillaries (Polymicro Technologies, Phoenix, AZ, USA) with $75 \mu \mathrm{m}$ ID and $365 \mu \mathrm{m}$ OD were dynamically coated with 5.0\% PVP overnight prior to use for DNA separations. A double-beam UV-vis spectrophotometer (Cintra 10e; GBC Scientific Equipment, Dandenong, Victoria, Australia) was used to measure the absorbance of the GNPs in aqueous and PEO solutions. A fluorometer (Aminco-Bowman Series 2; ThermoSpectronic, Pitsford, NY, USA) was used to measure the fluorescence of EtBr in the presence of GNPs. An H7100 transmission electron microscope (Hitachi High-Technologies, Tokyo, Japan) operating at $75 \mathrm{kV}$ was used to collect transmission electron microscopy (TEM) images of asprepared GNPs.

\subsection{Synthesis and characterization of GNPs}

The $56 \mathrm{~nm}$ GNPs were prepared according to a reported method [17]. Briefly, to an aliquot of $50.0 \mathrm{~mL}$ of $0.01 \%$ $\mathrm{NaAuCl}_{4}$ that was heated to boiling with a reflux condenser was rapidly added $0.3 \mathrm{~mL}$ of $1 \%$ trisodium citrate. The solution was boiled for another $8 \mathrm{~min}$, during which time the solution changed to purple, indicating the formation of $56 \mathrm{~nm}$ GNPs. The solution was sit aside while cooling to room temperature. The concentration of as-prepared $56 \mathrm{~nm}$ GNPs is denoted to be $1 \times$ that is about $2.96 \times 10^{13}$ particles/L (49 pm; $5.25 \times 10^{-3} \mathrm{wt} \%$ ) [18]. The UV-vis absorption spectrum of the as-prepared $1 \times$ GNPs was collected, which presents the surface plasmon resonance (SPR) band at $535 \mathrm{~nm}$, indicating the size of asprepared GNPs is as expected [19]. The size of as-prepared GNPs is further confirmed by the TEM image (not shown), which is $56( \pm 8.0 \%) \mathrm{nm}[17]$.

\subsection{Polymer solutions containing GNPs}

Glycine buffers containing $0.1-0.8 \times$ GNPs were separately prepared by mixing $5-40 \mathrm{~mL}$ of the as-prepared GNPs solution and $2.5 \mathrm{~mL}$ of $500 \mathrm{~mm}$ glycine solution (pH 6.0) prior to $\mathrm{pH}$ adjustment with $0.1 \mathrm{M} \mathrm{NaOH}$ to $\mathrm{pH}$ values 7.0-10.0 and then diluted with water to $50.0 \mathrm{~mL}$. To each of the prepared solutions was gradually added PEO (0.10-0.25 g). During the addition of PEO, a magnetic stirring rod was used to produce a well-homogeneous suspension. After the addition was completed, the suspensions were stirred for at least $1 \mathrm{~h}$ more. The asprepared solutions are denoted to be PEO(GNP) solutions, which are stable at $4^{\circ} \mathrm{C}$ for at least a week. Prior to use for CE separation, EtBr was added to the PEO(GNP) solutions while stirring using a magnetic stirring rod. The solutions were then degassed with a vacuum system in an ultrasonic tank for $10 \mathrm{~min}$. We note that PEO(GNP) solutions that were and were not subject to ultrasonication provided similar separation results (resolution and speed), indicating that possible mechanical degradation 
of PEO polymers caused by ultrasonication did not affect DNA separations. However, if the solution is not subject to ultrasonication, degassing for at least $1 \mathrm{~h}$ is needed to prevent from forming many spikes during separation.

\subsection{DNA separation by CE}

Prior to use, capillaries were dynamically coated with 5.0\% PVP overnight. Before conducting separations, PVP was flushed out with deionized water and then filled with PEO(GNP) solution by low pressure (syringe pushing). DNA was injected from the cathode end into the coated capillary filled with PEO(GNP) solution at $-1 \mathrm{kV}$ for $10 \mathrm{~s}$ and the separation was conducted at $-15 \mathrm{kV}$. After each run, $\mathrm{PEO}(\mathrm{GNP})$ solution was flushed out via low pressure and then the capillary was filled with fresh PEO(GNP). Between two different separation conditions, the capillary was dynamically coated with 5.0\% PVP to ensure reproducibility.

\section{Results and discussion}

\section{1 $\mathrm{pH}$ and $\mathrm{EtBr}$ dependence}

The conformation and charge density of DNA fragments, as well as the stability of the complexes between $\mathrm{EtBr}$ and DNA are pH-dependent [20-22]. In our previous study, we found that the stability of EtBr intercalated DNA increases with increasing $\mathrm{pH}$ ranging from 7.0 to 10.0 [23]. In this study, however, we have found that the separation of DNA markers $\mathrm{V}$ and $\mathrm{VI}$ is unsuccessful in terms of resolution at $\mathrm{pH} 10.0$ when using $0.2 \% \mathrm{PEO}(\mathrm{GNP})$. Using $0.2 \%$ $\mathrm{PEO}(\mathrm{GNP})$, the separation resolution (several unresolved broad peaks) and reproducibility are very poor at 7.0. Figure 1 reveals that, at $\mathrm{pH} 8.0,0.2 \% \mathrm{PEO}(0.3 \times \mathrm{GNP})$ provides greater resolving power for the same DNA fragments than does $0.2 \%$ PEO. The separation is fast (less than $5 \mathrm{~min}$ ), mainly because a low-viscosity sieving matrix $(<15 \mathrm{cP})$ was used and the separation was conducted at a high electric field $(375 \mathrm{~V} / \mathrm{cm})$. It is extremely important to point out that the reproducibility is excellent (RSD values for the migration times of all DNA fragments $<0.5 \%$ ). We observed increases in the fluorescence background and the formation of dark surface on the capillary wall after about 20 runs, indicating the adsorption of GNPs. The adsorption of GNPs is mainly due to its greater stability in PVP than that in PEO. Thus, we hypothesis that the interactions among GNPs, PVP (dynamically coated on the capillary wall), and PEO took place on the capillary wall. As a result, stable dynamic coating was achieved and there was no need to conduct dynamic coating of the capillary wall with PVP after at least 20 runs in the presence of GNPs. This should be of importance for high-throughput analysis of DNA using capillary arrays. In comparison to our previous result (conducted at $\mathrm{pH}$ 9.0) [14], we suggest that the impact of GNPs on DNA separation in terms of resolution and reproducibility is
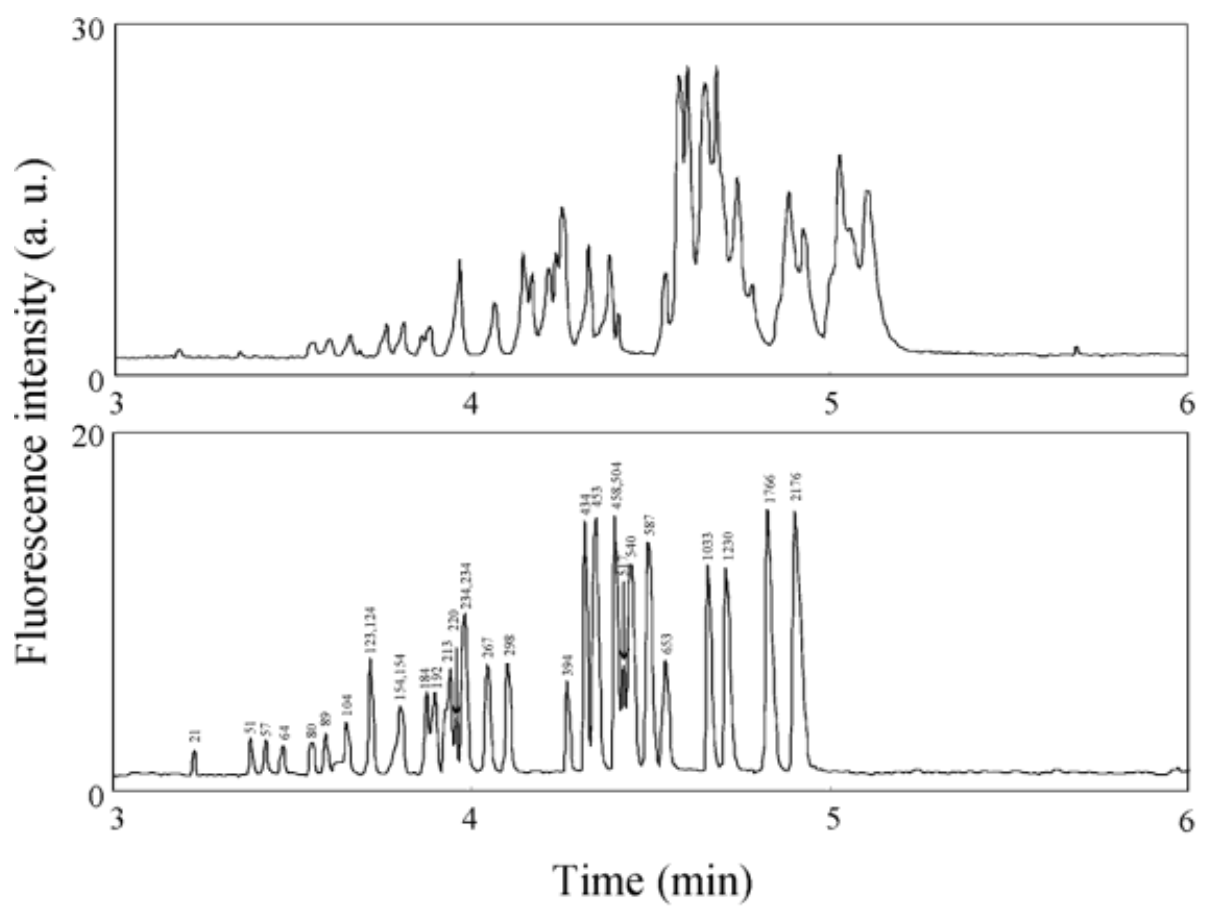

Figure 1. Separations of $10 \mu \mathrm{g} /$ $\mathrm{mL}$ DNA markers $\mathrm{V}$ and $\mathrm{VI}$ using (A) $0.2 \%$ PEO and (B) $0.2 \%$ $\mathrm{PEO}(0.3 \times$ GNPs). Electrophoresis conditions: PEO was prepared in $25 \mathrm{~mm}$ glycine $(\mathrm{pH}$ 8.0) containing $0.5 \mu \mathrm{g} / \mathrm{mL} \mathrm{EtBr}$; the DNA sample was prepared by mixing $25 \mu \mathrm{L}$ of $20 \mu \mathrm{g} / \mathrm{mL}$ DNA markers $\mathrm{V}$ and $\mathrm{Vl}$; electrokinetic injection was conducted at $-1 \mathrm{kV}$ for $10 \mathrm{~s}$; and separation was carried out at $-15 \mathrm{kV}$ $(-375 \mathrm{~V} / \mathrm{cm})$; capillary, $40 \mathrm{~cm}$ long (30 cm to the detector) fused-silica capillary with $365 \mu \mathrm{m}$ OD and $75 \mu \mathrm{m}$ ID. 
Table 1. Comparison of the separation of DNA markers $\mathrm{V}$ and $\mathrm{VI}$ at different $\mathrm{pH}$ values and $\mathrm{EtBr}$ concentrations ${ }^{\mathrm{a})}$

\begin{tabular}{|c|c|c|c|c|c|c|c|c|c|}
\hline \multirow[t]{2}{*}{$\mathrm{pH}$} & \multirow{2}{*}{$\begin{array}{l}\text { EtBr } \\
(\mu \mathrm{g} / \mathrm{mL})\end{array}$} & \multicolumn{2}{|c|}{ Migration time (min) (RSD\%) } & \multicolumn{2}{|c|}{ Resolved peak numbers } & \multicolumn{4}{|c|}{ Theoretical plates $\left(10^{6} / \mathrm{m}\right)$} \\
\hline & & $51 \mathrm{bp}$ & 2176 bp & $154-298 b p^{b)}$ & $394-653 b p^{c)}$ & $89 \mathrm{bp}$ & $298 \mathrm{bp}$ & $653 \mathrm{bp}$ & $1033 \mathrm{bp}$ \\
\hline 8.0 & 0.1 & $3.34(1.5)$ & $4.77(1.9)$ & 7 & 7 & 0.61 & 0.81 & 0.44 & 1.04 \\
\hline 8.0 & 0.5 & $3.38(0.3)$ & $4.90(0.3)$ & 8 & 7 & 0.64 & 0.84 & 0.46 & 1.08 \\
\hline 8.0 & 5.0 & $3.45(1.9)$ & $4.98(1.5)$ & 7 & 8 & 0.66 & 0.83 & 0.47 & 0.50 \\
\hline 9.0 & 0.1 & $3.34(0.3)$ & $4.75(0.4)$ & 8 & 7 & 2.60 & 0.79 & 0.98 & 1.07 \\
\hline 9.0 & 0.5 & $3.45(0.2)$ & $4.92(0.3)$ & 8 & 8 & 2.55 & 3.18 & 1.00 & 1.07 \\
\hline 9.0 & 5.0 & 3.56 (1.5) & $5.13(1.7)$ & 7 & 8 & 2.70 & 2.88 & 0.93 & 1.16 \\
\hline 10.0 & 0.1 & $2.96^{\mathrm{d})}(0.2)$ & $4.02(0.3)$ & 7 & 7 & -d) & 2.04 & 0.64 & 0.73 \\
\hline 10.0 & 0.5 & $2.96^{\mathrm{d})}(0.2)$ & $4.13(0.5)$ & 7 & 8 & - & 0.53 & 2.70 & 0.75 \\
\hline 10.0 & 5.0 & $2.96^{\mathrm{d})}(0.5)$ & $4.33(0.7)$ & 6 & 7 & - & 0.55 & 0.33 & 0.21 \\
\hline
\end{tabular}

a) Conditions are the same as in Fig. 1, 0.2\% PEO(0.3 $\times$ GNPs).

b) Ten peaks are expected.

c) Nine peaks are expected.

d) Not separated from $104 \mathrm{bp}$

more significant at $\mathrm{pH} 9.0$ compared to that at $\mathrm{pH}$ 8.0. This is mainly because of a greater sieving power of PEO in the absence of GNPs at pH $8.0[23,24]$.

Once forming complexes with cationic intercalating dyes such as EtBr, the DNA chain becomes longer and stiffer and the net charges of the DNA fragments decrease, depending on DNA/dye ratio [25-27]. In consequence, intercalated DNA migrates more slowly than free DNA. In the presence of electroosmotic flow (EOF), we have found that speed and resolution can be optimized by controlling EtBr concentration when using 1.5\% PEO (without GNPs) at $\mathrm{pH} 8.0$ [28]. It has also been suggested that EtBr intercalated with DNA in a manner of one molecule to $5 \mathrm{bp}$ and excess $\mathrm{EtBr}$ may interact with phosphate residues through Coulombic interactions that leads to loss of resolution [26]. Table 1 presents that the appropriate $\mathrm{EtBr}$ concentration was $0.5 \mu \mathrm{g} / \mathrm{mL}$ when conducting the separations of $10.0 \mu \mathrm{g} / \mathrm{mL}$ DNA markers $\mathrm{V}$ and $\mathrm{VI}$ using $0.2 \%$ $\mathrm{PEO}(0.3 \times \mathrm{GNPs})$ at $\mathrm{pH}$ 8.0-10.0. Under this condition, about every 12 bp DNA intercalates one EtBr molecule if we do not account the interaction between GNPs and EtBr. However, we have shown adsorption of $\mathrm{EtBr}$ on GNPs [29]. Since fluorescence resonance energy transfer occurs between EtBr and GNPs, it is easy to estimate the saturated amounts of $\mathrm{EtBr}$ on each GNP particle from a plot of fluorescence intensity at $610 \mathrm{~nm}$ as a function of $\mathrm{EtBr}$ concentration. The total $\mathrm{EtBr}$ amount used in this study is about 15 times higher than the saturated $\mathrm{EtBr}$ molecules on the GNPs surface at $\mathrm{pH}$ 9.0. Thus, there are greater than 12 bp DNA intercalate one EtBr molecule. When conducting the separation at $\mathrm{pH} 9.0$, the efficiency is great $(>0.9$ million plates $/ \mathrm{m})$ and the reproducibility is excellent $(<0.5 \%)$. Table 1 also presents that the separa- tion time becomes longer with increasing EtBr concentration as expected. At the same $\mathrm{pH}$, the reproducibility is relatively poor in the case of using $5.0 \mu \mathrm{g} / \mathrm{mL} \mathrm{EtBr}$ that is about four times higher than the optimum concentration $(1.2 \mu \mathrm{g} / \mathrm{mL} \mathrm{EtBr}$ based on one $\mathrm{EtBr}$ intercalates $5 \mathrm{bp}$ DNA). Thus, the loss in resolution is expected as a result of interaction between $\mathrm{EtBr}$ and phosphate residues in DNA. It is also partially due to slight aggregation of GNPs, supported by a small change in the absorption at $535 \mathrm{~nm}$.

\subsection{GNP, PEO, and EtBr dependence}

To further investigate the impact of GNPs on DNA separation, $0.2 \%$ PEO solutions containing different amounts of GNPs and EtBr were used. The amounts of $\mathrm{EtBr}(\mu \mathrm{g} / \mathrm{mL})$ and GNPs in $0.2 \%$ PEO are (EtBr/GNP): 0.17/0.1 $\times, 0.50 /$ $0.3 \times, 0.83 / 0.5 \times$, and $1.33 / 0.8 \times$. Of these solutions, the last one has the highest free $\mathrm{EtBr}$ (not bound to GNPs) concentration in the bulk solution. Thus, the solution should provide the longest separation time if the GNP impact is ignored. In contrast, Table 2 presents that the separation time becomes shorter with increasing the concentration of GNPs. Since the currents are low $(<5.0 \mu \mathrm{A})$ and the viscosities are almost the same $(<15 \mathrm{cP})$, the decrease in migration time with increasing GNP concentration is likely due to changes in the morphologies of PEO matrices. We have shown that GNPs get closer once the interactions among PEO molecules take place, which is supported by the change in the absorption of SPR band at $535 \mathrm{~nm}$ and the TEM images [19]. Table 2 also presents a slightly better reproducibility when using higher concentrations of GNPs, which is probably due to 
Table 2. Effect of GNPs and EtBr on the separations of DNA markers $V$ and VI using $0.2 \%$ PEO(GNPs) at pH 9.0

\begin{tabular}{|c|c|c|c|c|c|c|c|c|c|c|c|c|c|c|}
\hline \multirow[t]{2}{*}{ GNPS $^{\text {b) }}$} & \multicolumn{2}{|c|}{$\begin{array}{l}\text { Migration time } \\
\text { (min) (RSD\%) }\end{array}$} & \multicolumn{2}{|c|}{$\begin{array}{l}\text { Resolved peak } \\
\text { numbers }\end{array}$} & \multicolumn{4}{|c|}{ Theoretical plates $\left(10^{6} / \mathrm{m}\right)$} & \multicolumn{6}{|c|}{ Resolution (bp/bp) } \\
\hline & 51 bp & 2176 bp & $\begin{array}{l}154- \\
298 \mathrm{bp}^{\mathrm{c})}\end{array}$ & $\begin{array}{l}394- \\
653 \text { bp }^{\mathrm{d})}\end{array}$ & 89 bp & 298 bp & 653 bp & 1033 bp & $51 / 57$ & $\begin{array}{l}184 / \\
192\end{array}$ & $\begin{array}{l}220 / \\
234\end{array}$ & $\begin{array}{l}517 / \\
540\end{array}$ & $\begin{array}{l}1033 / \\
1230\end{array}$ & $\begin{array}{l}1766 / \\
2176\end{array}$ \\
\hline $0.1 \times$ & $3.78(0.5)$ & $5.37(0.4)$ & 8 & 8 & 0.81 & 3.18 & 1.00 & 1.19 & 3.0 & 0.9 & 1.2 & 2.0 & 2.7 & 3.0 \\
\hline $0.3 \times$ & $3.45(0.2)$ & $4.92(0.3)$ & 8 & 8 & 2.55 & 3.18 & 1.00 & 1.07 & 2.4 & 1.2 & 1.2 & 2.4 & 2.8 & 3.8 \\
\hline $0.5 \times$ & $3.33(0.2)$ & $4.63(0.3)$ & 8 & 8 & 2.39 & 3.13 & 3.60 & 0.98 & 1.0 & 0.5 & 0.2 & 0.8 & 4.7 & 3.0 \\
\hline $0.8 \times$ & $3.17(0.1)$ & $4.51(0.2)$ & 6 & 8 & 2.12 & 2.63 & 3.30 & 3.60 & 0.9 & 0 & 0 & 1.7 & 4.1 & 3.0 \\
\hline
\end{tabular}

a) Conditions are the same as in Fig. 1.

b) EtBr concentrations are $0.17,0.5,0.83$, and $1.33 \mu \mathrm{g} / \mathrm{mL}$, respectively.

c) Ten peaks are expected.

d) Nine peaks are expected.

greater amounts of GNPs adsorbed on the capillary surface, leading to weak interactions (adsorption) with DNA. Although the separation is faster and more reproducible using higher concentrations of GNPs, the resolution for small DNA fragments ( $<300 \mathrm{bp}$ ) is sacrificed.

Table 3 shows the impact of GNPs, PEO, and $\mathrm{EtBr}$ on DNA separation. At the same EtBr concentration, 0.5\% $\mathrm{PEO}(\mathrm{GNP})$ provides a longer separation time and greater resolving power for small DNA fragments $(<220 \mathrm{bp}$ ) than does $0.2 \%$ PEO(GNP). The results are mainly due to a higher viscosity and small pore sizes (greater sieving power for small DNA fragments) of $0.5 \%$ PEO, which are in good agreement with our previous result using PEO in the absence of GNPs [16, 23]. Table 3 clearly shows that at low EtBr concentrations $(<5.0 \mu \mathrm{g} / \mathrm{mL})$, the 123 and $124 \mathrm{bp}$ fragments are unresolved using $0.2 \%$ or $0.5 \%$ PEO(GNP) solutions, while they are partially resolved using $0.5 \% \mathrm{PEO}(\mathrm{GNP})$ containing greater than 5.0 or $13.3 \mathrm{~g} / \mathrm{mL}$ EtBr. The increase in the differential migration time (selectivity) between the 123 and 124 bp fragments with increasing EtBr and PEO concentration takes account for better resolution. We note that band broadening for the large DNA fragments ( $>1766 \mathrm{bp}$ ) occurred at high $\mathrm{EtBr}$ concentrations, possibly due to side reactions and diffusion. Overall, the results listed in Table 3 show $0.5 \% \mathrm{PEO}(0.8 \times \mathrm{GNPs})$ containing $13.3 \mu \mathrm{g} / \mathrm{mL} \mathrm{EtBr}$ is suitable for the separation of DNA fragments with sizes less than $2176 \mathrm{bp}$ in terms of resolution if speed is not an issue.

\subsection{Separation of $8 \mathrm{bp}-23.1 \mathrm{kbp}$ DNA}

To test the feature of PEO(GNP) for the separation of DNA with a wide range in size, we conducted the separation of a DNA sample consisting of lambda DNA, Haell digest, and DNA marker $\mathrm{V}$. The sample contains DNA ranging in

Table 3. Effects of the concentrations of PEO, EtBr, and GNPs on the separations of DNA markers $\mathrm{V}$ and $\left.\mathrm{V}\right|^{\mathrm{a})}$

\begin{tabular}{|c|c|c|c|c|c|c|c|c|c|c|}
\hline \multirow{2}{*}{$\begin{array}{l}\text { PE0 } \\
(\%)\end{array}$} & \multirow[t]{2}{*}{ GNPs } & \multirow{2}{*}{$\begin{array}{l}\text { EtBr } \\
(\mu \mathrm{g} / \mathrm{mL})\end{array}$} & \multicolumn{2}{|c|}{ Resolved peak numbers } & \multicolumn{2}{|c|}{ Migration time(min) (RSD) } & \multicolumn{4}{|c|}{ Resolution (bp/bp) } \\
\hline & & & $8-124 b p^{b)}$ & $154-298 b p^{c)}$ & 51 bp & 2176 bp & $123 / 124$ & $184 / 192$ & $20 / 234$ & $1766 / 2176$ \\
\hline 0.2 & $0.3 \times$ & 0.5 & $8(21)^{d)}$ & 8 & $3.45(0.2)$ & $4.92(0.3)$ & 0 & 1.2 & 1.2 & 3.8 \\
\hline 0.2 & $0.3 \times$ & 5.0 & $8(21)$ & 7 & $3.56(1.5)$ & $5.13(1.7)$ & 0 & 0 & 1.8 & 3.3 \\
\hline 0.2 & $0.8 \times$ & 1.33 & 7 (51) & 6 & $3.17(0.1)$ & $4.51(0.2)$ & 0 & 0 & 0 & 3.0 \\
\hline 0.2 & $0.8 \times$ & 13.3 & $8(21)$ & 7 & $3.41(0.4)$ & $4.93(0.6)$ & 0 & 0 & 1.2 & 3.7 \\
\hline 0.5 & $0.3 \times$ & 0.5 & $9(18)$ & 8 & $4.53(0.9)$ & $7.41(0.6)$ & 0 & 2.2 & 1.2 & 3.8 \\
\hline 0.5 & $0.3 \times$ & 5.0 & $10(18)$ & 8 & $4.48(1.4)$ & $7.57(1.1)$ & 0.6 & 3.0 & 1.8 & 4.4 \\
\hline 0.5 & $0.8 \times$ & 1.33 & 9 (18) & 8 & $4.23(0.9)$ & $6.98(0.8)$ & 0 & 1.3 & 1.6 & 3.8 \\
\hline 0.5 & $0.8 \times$ & 13.3 & 10 (18) & 9 & $5.13(0.7)$ & $8.48(0.5)$ & 0.7 & 1.1 & 7.1 & 4.7 \\
\hline
\end{tabular}
a) Conditions are the same as in Fig. 1.
b) Twelve peaks are expected.
c) Ten peaks are expected.
d) Smallest detected DNA fragment 


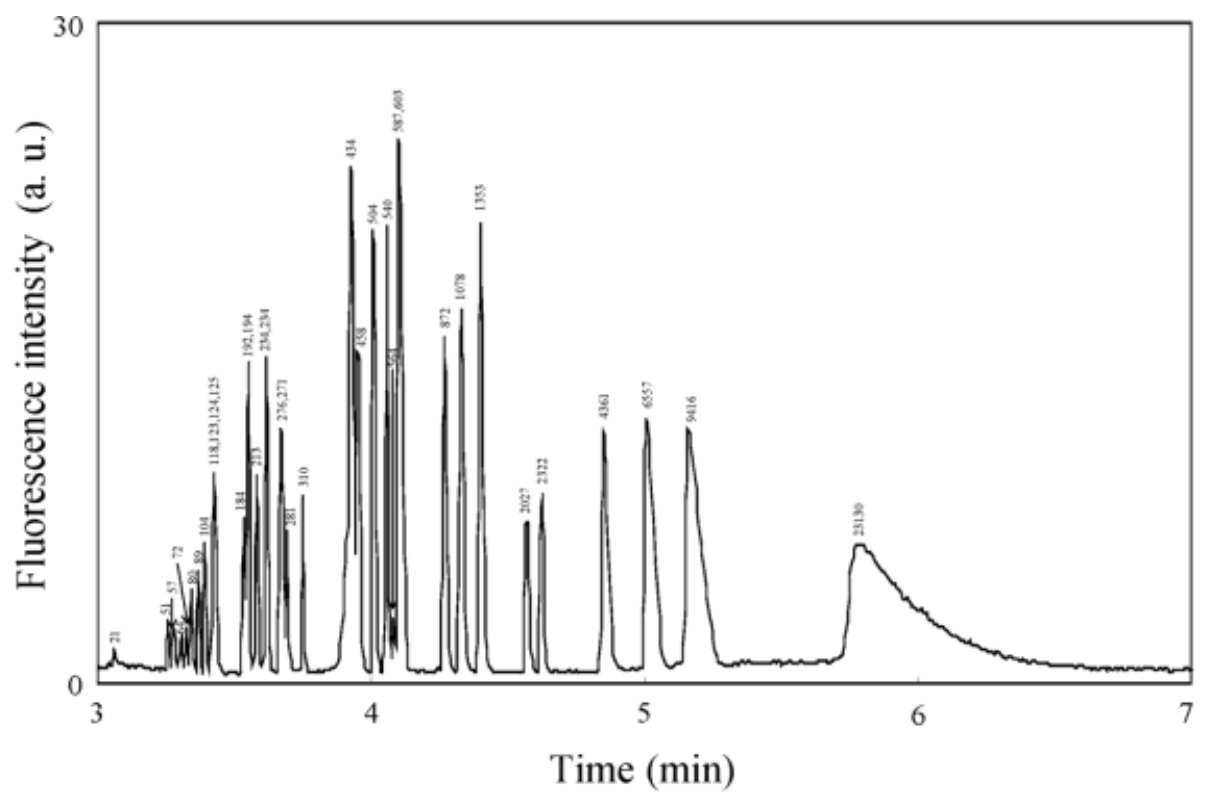

Figure 2. Separation of a mixture of DNA markers at $-15 \mathrm{kV}$ using $0.2 \% \mathrm{PEO}(0.3 \times \mathrm{GNPs})$. $\mathrm{PEO}(0.3 \times \mathrm{GNPs})$ was prepared in a solution consisting of $25.0 \mathrm{~mm}$ glycine, $0.01 \mathrm{~mm}$ citrate and $0.5 \mu \mathrm{g} / \mathrm{mL}$ EtBr. DNA mixture consisted of $20 \mu \mathrm{g} / \mathrm{mL}$ lambda DNA Hindlll digest, $5 \mu \mathrm{g} / \mathrm{mL} \Phi \times 174$ RF NDA-HaellI digest, and $10 \mu \mathrm{g} / \mathrm{mL}$ DNA markers $\mathrm{V}$. Other conditions are the same as in Fig. 1. size from 8 to $23130 \mathrm{bp}$ and has been separated under stepwise changes of PEO concentration in the presence of EOF [30], in which the $51 \mathrm{bp}$ fragment is the smallest detected DNA fragment. Figure 2 shows the separation was accomplished in $7 \mathrm{~min}$, which is faster than the stepwise technique (12 min). This technique is capable of detecting the $21 \mathrm{bp}$ fragment and provides excellent reproducibility $(<0.7 \% \mathrm{RSD}$ for the migration time of the $23130 \mathrm{bp}$ fragment), likely because of reduction of the interaction of DNA with the capillary wall in the presence of GNPs. It is important to note that adding citrate $(0.01 \mathrm{~mm})$ to $\mathrm{PEO}$ solution is essential for improving resolution for small DNA fragments [14]. In that report, we suggested that the increase in the mobility of DNA in the presence of citrate is a result of the interaction between DNA and citrate. In comparison to the use of ultradiluted HEC solutions [31], PEO(GNP) provides greater resolving power, a wider separation range, and rapidity. When compared to the stepwise technique [30], this approach provides poor resolution for the small DNA fragments ( $<504$ bp) while better resolution for the large DNA fragments. This is mainly because a higher concentration of PEO solution was used and DNA migrated against EOF in the gradient technique.

\section{Concluding remarks}

We have investigated the impacts of PEO, GNPs, EtBr, and $\mathrm{pH}$ on the separation of DNA by CE. In the presence of GNPs, $0.2 \%$ PEO at $\mathrm{pH} 8.0$ and 9.0 both provide high resolving power for the DNA separation. However, the impact of GNPs on DNA separation is more significant at
$\mathrm{pH} 9.0$ than at $\mathrm{pH}$ 8.0. With increasing GNP concentration, the reproducibility improves possibly as a result of weaker interactions of DNA with the capillary wall. However, at constant PEO and EtBr concentrations, high concentrations of GNPs are not desirable in terms of resolution. The separation of DNA markers $\mathrm{V}$ and $\mathrm{VI}$ is successful by using $0.2 \% \mathrm{PEO}(0.3 \times \mathrm{GNPs})$ at $\mathrm{pH} 9.0$, with the advantages of rapidity, high resolving power, and excellent reproducibility. Using a similar condition, we have demonstrated the separation of DNA fragments ranging in size from 21 to $23130 \mathrm{bp}$ in $7 \mathrm{~min}$. Although we have nicely demonstrated the separations of DNA using PEO(GNP) solutions, the role of GNPs playing on improving resolution and reproducibility is still unclear. In order to further explore the effect of GNPs on DNA separation, scanning electron microscopy, TEM, and/or atomic force microscopy measurements of the capillary wall and PEO(GNP) solutions are needed and are being conducted in this group.

This work was supported by the National Science Council of the Republic of China under contract numbers NSC 92-2120-M002-001 and 92-2113-M002-048.

Received January 9, 2004

\section{References}

[1] Zhang, J., Yang, M., Puyang, X., Fang, Y., Cook, L. M., Dovichi, N. J., Anal. Chem. 2001, 73, 1234-1239.

[2] Cantafora, A., Blotta, I., Bruzzese, N., Calandra, S., Bertolini, S., Electrophoresis 2001, 22, 4012-4015.

[3] Medintz, I. L., Berti, L., Emrich, C. A., Tom, J., Scherer, J. R., Mathies, R. A., Clin. Chem. 2001, 47, 1614-1621. 
[4] Sartori, A., Barbier, V., Viovy, J.-L., Electrophoresis 2003, 24, 421-440.

[5] Chen, H.-S., Chang, H.-T., Electrophoresis 1998, 19, 31493153.

[6] Wei, W., Yeung, E. S., J. Chromatogr. B 2000, 745, 221-230.

[7] Sunada, W. M., Blanch, H. W., Electrophoresis 1998, 19, 3128-3136.

[8] McIntosh, S. L., Deligeorgiev, T. G., Gadjev, N. I., McGown, L. B., Electrophoresis 2002, 23, 1473-1479.

[9] Li, H., Xue, G., Yeung, E. S., Anal. Chem. 2001, 73, 15371543.

[10] Chiari, M., Riva, S., Gelain, A., Vitale, A., Turati, E., J. Chromatogr. A 1997, 781, 347-355.

[11] Han, F., Huynh, B. H., Ma, Y., Lin, B., Anal. Chem. 1999, 71, 2385-2389.

[12] Xu, F., Jabasini, M., Baba, Y., Electrophoresis 2002, 23, 3608-3614.

[13] Liang, D., Song, L., Chen, Z., Chu, B., Electrophoresis 2001, 22, 1997-2003.

[14] Huang, M.-F., Huang, C.-C., Chang, H.-T., Electrophoresis 2003, 24, 2896-2902.

[15] Lin, Y.-W., Huang, M.-J., Chang, H.-T., J. Chromatogr. A 2003, 1014, 47-55.

[16] Chen, H.-S., Chang, H.-T., Anal. Chem. 1999, 71, 20332036.

[17] Frens, G., Nature 1973, 241, 20-22.
[18] Jana, N. R., Gearheart, L., Murphy, C. J., Langmuir 2001, 17, 6782-6786.

[19] Huang, C.-C., Huang, Y.-F., Chang, H.-T., Nanosci. Nanotechnol., in press.

[20] Wolfe, A. R., Meehan, T., Nucleic Acids Res. 1994, 22, 31473150.

[21] LePecq, J.-B., Paoletti, C., J. Mol. Biol. 1967, 27, 87-106.

[22] Oana, H., Hammond, R. W., Schwinefus, J. J., Wang, S.-C., Doi, M., Morris, M. D., Anal. Chem. 1998, 70, 574-579.

[23] Tseng, W.-L., Chang, H.-T., Electrophoresis 2001, 22, 763770.

[24] Chang, H.-T., Yeung, E. S., J. Chromatogr. B 1995, 669, 113120.

[25] Carlsson, C., Larsson, A., Jonsson, M., Electrophoresis 1996, 17, 642-651.

[26] Kim, Y., Morris, M. D., Anal. Chem. 1994, 66, 1168-1174.

[27] Liang, D., Zhang, J., Chu, B., Electrophoresis 2003, 24, 3348-3355.

[28] Huang, M.-F., Hsu, C.-E., Tseng, W.-L., Lin, Y.-C., Chang, H.-T., Electrophoresis 2001, 22, 2281-2290.

[29] Huang, M.-F., Kuo, Y.-C., Huang, C.-C., Chang, H. -T., Anal. Chem. 2004, 76, 192-196.

[30] Kuo, I.-T., Chiu, T.-C., Chang, H.-T., Electrophoresis 2003, 24, 3339-3347.

[31] Barron, A. E., Blanch, H. W., Soane, D. S., Electrophoresis 1994, 15, 597-615. 